\title{
Toimijuuden ja identiteetin yksilölliset ja sosiaaliset painotukset korkeakoulutettujen urapoluilla
}

\begin{abstract}
1
Korkeakoulutettujen uratarinat osoittavat, miten urat rakentuvat ja millaisia yksilöllisiä ja sosiaalisia painotuksia toimijuus ja identiteetti niissä saavat. Uratarinoista piirtyvät uratyyppitarinat kuvaavat, miten yksilöllisesti tai sosiaaliseen yhteisöön nojautuen kukin uratyyppi tekee omaa uraa koskevia valintoja ja määrittää, mitä haluaa olla työssään. Moninaiset urapolut luovat pohjaa sille, miten sekä koulutus- ja työllisyyspolitiikassa että koulutuksen ja ohjauksen kentillä voidaan tunnistaa ja tukea niiden rakentumisen tapoja.
\end{abstract}

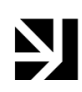
KORKEAKOUlutusta ARVOSTETAan Suomessa, koska sen nähdään parantavan yksilön mahdollisuuksia menestyä urallaan ja sopeutua työelämän muutoksiin. Yhteiskunnan näkökulmasta korkea koulutustaso edistää muun muassa yleistä hyvinvointia ja parantaa kansallista kilpailukykyä. (Rouhelo 2009.)

Vaikka korkeakoulutetut työllistyvät edelleen hyvin verrattuna matalammin koulutettuihin, heidänkin työllistymistään haastavat työelämän voimakas rakennemuutos ja korkeakoulututkinnon suorittaneiden suuri määrä verrattuna aiempiin vuosikymmeniin. Korkeakoulutettujen määrä on 2000-luvulta lähtien lisääntynyt Suomessa: vuoden 2019 loppuun mennessä korkea-asteen tutkinnon oli suorittanut kolmannes väestöstä (Findikaattori 2021). Samaan aikaan työttömyys on kuitenkin kasvanut kaikilla korkeakoulutasoilla ja -aloilla (Työ- ja elinkeinoministeriö 2016).

Korkeakoulutettujen työllistymisongelmat koskevat useammin naisia ja ammattikorkeakoulututkinnon suorittaneita kuin miehiä ja yliopistotutkinnon suorittaneita (Vuorinen-Lampila 2014; Ojala, Isopahkala-Bouret \& Haltia 2018). Erityisesti vastavalmistuneilla ja generalistialan tutkinnon suorittaneilla, kuten humanisteilla, on havaittu työllistymis- 
KOKO URAA KOSKEVASTA

\section{IDENTITEETIST $\ddot{A}$ ELI}

\section{URAIDENTITEETIST $\ddot{A}$ ON TULLUT YKSILÖLLE YHÄ TÄRKEÄMPI.}

ongelmia (Rouhelo 2009). Vastaavaa kehitystä on todettu kansainvälisessä tutkimuksessa muun muassa Isossa-Britanniassa, missä korkeakoulutettujen määrän lisääntyminen on vaikeuttanut tämän ryhmän työllistymistä (Tomlinson 2008).

Pitkäaikaistyöttömyys lisääntyi koronaviruspandemian myötä vuosina 2020 ja 2021 kaikissa koulutusryhmissä, ja korkeakoulutetuista suhteessa eniten ylemmän korkeakoulututkinnon suorittaneilla. Korkeakoulutettuja oli huhtikuussa 2021 työttömänä 40 306, joista pitkäaikaistyöttömiä oli 14 803. (Akava Works 2021.) Vaatimukset oman työllistettävyyden ylläpitämisestä ja jatkuvasta osaamisen kehittämisestä koskevat myös työllistyneitä (Mauno, Minkkinen \& Auvinen 2019; Rantanen ym. 2021). Muun muassa sukupuoli, yhteiskuntaluokka ja ikä määrittävät nekin työnhakijan asemoitumista työmarkkinoilla (Isopahkala-Bouret \& Siivonen 2016).

Kun korkeakoulutettujen työurat ovat aiempaa epävarmempia, koko uraa koskevasta identiteetistä eli uraidentiteetistä on tullut yksilölle yhä tärkeämpi: miten oma koulutus- ja työura hahmottuu ja millaisina uraa koskevat tavoitteet, odotukset ja mielenkiinnonkohteet nähdään (Carruthers \& Uzzi 2000; Terrén 2002; Anttila 2011)? Työmarkkinoiden epävarmuus edellyttää yksilöiltä vahvaa toimijuutta (Eteläpelto ym. 2013), koska omat päätökset ja valinnat ovat urapolkujen rakentumisen keskiössä (LaPointe 2014). Toimijuuden ymmärretään rakentuvan ja mahdollistuvan vuorovaikutteisissa suhteissa niin työelämässä kuin muilla elämänkentillä (Åkerblad 2014; LaPointe 2014; de Vos ym. 2020).

Aikuiskasvatuksen näkökulmasta toimijuuteen perehtyneiden tutkijoiden Katja Vähäsantasen, Susanna Paloniemen, Eija Räikkösen, Päivi Hökän ja
Anneli Eteläpellon (2017) kehittämässä teoriassa ammatillisen toimijuuden rakenteessa on kolme ulottuvuutta: 1) vaikuttaminen työssä, 2) työkäytäntöjen kehittäminen ja 3) ammatillisen identiteetin neuvottelu. Etenkin työn tai työympäristön muuttuessa identiteettiä tarkastellaan lisäksi suhteessa toimijuuteen - millaisia identiteetin suuntaiset tavoitteet ja teot olisivat sekä miten ammatillista identiteettiä rakennetaan ja muokataan suhteessa muutoksiin (Vähäsantanen ym. 2017, 18). Identiteetin ja toimijuuden erillisyyttä mutta yhteenkietouneisuutta voidaan arjen vertauskuvin määritellä siten, että identiteetti uraa koskevine tavoitteineen ja unelmineen on yksilön kompassi, kun tämä suunnistaa eli toteuttaa toimijuuttaan päätöksineen ja valintoineen koulutuksessa ja työelämässä.

Muutokset yhteiskunnassa ja alati lisääntyvät työelämän vaatimukset haastavat tutkimaan korkeakoulutettujen urapolkuja toimijuuden ja identiteetin näkökulmasta. Näin tunnistetaan sekä korkeakoulutettujen urien rakentumisen tapoja että yksilön ja yhteiskunnan asettamien odotusten ja tavoitteiden merkitystä poluilla.

Tutkimme korkeakoulutettujen toimijuutta ja identiteettiä heidän uratarinoissaan seuraavien tutkimuskysymysten kautta:

1) Millaisia urapolkuja korkeakoulutettujen uratarinoista on tunnistettavissa?

2) Millaisia toimijuuden ja identiteetin yksilöllisiä ja sosiaalisia painotuksia korkeakoulutettujen uratarinat sisältävät?

Yliopistojen ja ammattikorkeakoulujen opiskelijoille suunnatun valtakunnallisen Töissä.fi-verkkopalvelun kautta saadussa aineistossa oli 462 korkeakoulutetun uratarinaa. Laaja aineisto mahdollisti moniäänisen kerronnallisen tarkastelun siitä, miten monin eri tavoin korkeakoulutetut rakentavat omia urapolkujaan, kun työurien epävarmuus lisääntyy. Tarkastelemme toimijuuden ja identiteetin yksilöllisiä ja sosiaalisia painotuksia uratyypeittäin. Tuloksissa luomme näin uudenlaisen teoretisoinnin korkeakoulutettujen urapoluista. 


\section{URATEORIOIDEN UUDET MUOTOILUT} JA HAASTEET

Ura-käsitteen taustaa voidaan hahmottaa latinankielisen carraria-termin avulla. Vaunutietä tarkoittavan termin pohjalta ura voidaan nähdä selvärajaisena elämänkulkuna ja työhistorian kuvauksena. (Onnismaa 2011.) Perinteiset urateoriat selittävätkin yksilöiden ammatillista suuntautumista, ammatinvalinnan prosesseja ja urakehitystä muun muassa ikäkausittaisten kehitysvaiheiden ja persoonallisuuden ominaisuuksien märittymisen mukaan (esim. Super 1954; Holland 1985).

Talouden, teknologian ja kulttuuristen muutosten myötä 1980-90-luvuilla käsitykset urasta alkoivat muuttua (Onnismaa 2003), ja ura-käsitettä ryhdyttiin muotoilemaan uudelleen (Arnold \& Jackson 1997). Ura alettiin nähdä fragmentoituneena, ja urasuunnittelun tuen tarve tunnistettiin etenkin koulutus- ja työelämän siirtymävaiheissa. Samalla subjektiivisen uran merkitys alkoi korostua, koska objektiivisia uramittareita oli vaikea löytää, kun yksilöt loivat oman uratarinansa.

Uudemmat urateoriat (esim. Lent ym. 1996; Savickas 2005; Niles 2011; de Vos ym. 2020) alkoivat kehittyä 1980-90-lukujen muutosten myötä. Niissä korostuvat vahva itsetuntemus, yksilölliset elämäntarinat, yksilön ja ympäristön välinen vuorovaikutus sekä näiden vaikutus yksilön toimijuuteen ja uravalintoihin. Ne myös heijastavat eri tavoin epävarmaa ja alati muuttuvaa koulutus- ja työelämää ja korostavat muun muassa sattumien merkitystä (Mitchell, Levin \& Krumboltz 1999) sekä toivokeskeisen uraohjauksen näkökulmaa (Niles 2011). Yksilön toimijuuden kokemus muotoutuu yhtältä hänen vaikuttaessaan proaktiivisesti sekä toisaalta sopeutuessaan tilanteen tai tarpeen mukaan oman elämänsä eri konteksteihin, joihin työelämäkin eri vaiheineen kuuluu (mm. de Vos ym. 2020). Uria on myös tyypitelty eri tavoin. Esimerkiksi proteaaninen urakäsitys korostaa yksilön roolia itsensä kehittäjänä organisaation sijasta (Hall 1976). Rajattomassa urakäsityksessä puolestaan keskeistä on yksilöiden joustava liikkuminen työtehtävästä toiseen ja verkostot yksilön urakehityksen takaajina (Arthur \& Rousseau 2000).
Eri-ikäisten ihmisten uria, urasiirtymiä ja uratarinoita on tutkittu 2000-luvulta lähtien verrattain paljon sekä Suomessa (esim. Rouhelo 2008, 2009; LaPointe 2011; Marttila 2015) että kansainvälisesti (esim. Sampson ym. 2014). Koulutus- ja työelämän sekä globaalin, nopeasti muuttuvan maailman murrosten myötä uudet urateoriat ovat tulleet haastetuiksi. Ensinnäkin ura- ja elämänsuunnittelun kysymykset ovat monimutkaistuneet. Toiseksi uraan liittyvät merkitykset syntyvät suhteissa ja dialogissa, jolloin ura- ja elämänsuunnittelun tarkastelun tulee pohjautua yhä tiiviimmin sekä teoriaan että yksilön ja työn välisten suhteiden dynamiikkaan. Kolmanneksi urasuunnittelu jatkuu läpi elämän. (Onnismaa 2003; de Vos ym. 2020)

Työurien pidentäminen on ollut yksi Sanna Marinin (sd) hallituksen keskeisiä tavoitteita työllisyysasteen nostamiseksi väestön ikääntyessä. Niin tutkimuksessa kuin poliittisessa päätöksenteossa on ollut vallalla käsitys yksilön kyvystä hallita ympäristönsä tapahtumia sekä suoraviivaisten ja yhden ammatin työurien korostaminen. Koulutus- ja työelämän yhä monimutkaisempien, kontekstiin sitoutuneiden urapolkujen myötä tarvitaan myös henkilökohtaista ohjausta oman työuran hahmottamiseksi. (Järvensivu \& Pulkki 2019; OECD 2021.)

\section{TOIMIJUUS JA IDENTITEETTI URATARINOISSA}

Työelämän ja aikuiskasvatuksen tutkimuksessa toimijuutta on tarkasteltu 2010-luvulla eri näkökulmista (esim. Eteläpelto ym. 2014; Goller \& Paloniemi 2017). Toimijuus-käsitteen juuret ovat yhteiskuntatieteissä, mutta sittemmin termiä on hyödynnetty muillakin tieteenaloilla, kuten antropologiassa ja psykologiassa (Eteläpelto ym. 2013, 2014).

'Toimijuus' voidaan ymmärtää niin kyvykkyytenä ja ominaisuutena kuin tekoina. Tässä tutkimuksessa hyödynnämme toimijuuden määritelmää subjektikeskeisen sosiokulttuurisen lähestymistavan (Eteläpelto ym. 2014) ja elämänkulkututkimuksen (Vanhalakka-Ruoho 2014) näkökulmista. Subjektikeskeisessä sosiokulttuurisessa lähestymistavassa ammatillinen toimijuus nähdään prosessina, joka ilmenee työntekijöiden tai työyhteisöjen vaikuttaessa, 
URAIDENTITEETTI KUVAA

SIT $\ddot{A}$, MIT $\ddot{A}$ YKSILÖ ON TAI

HALUAA OLLA TYÖSSÄ̈̈N.

tehdessä valintoja ja päätöksiä sekä ottaessa kantaa työhönsä ja ammatillisiin identiteetteihinsä. Lähestymistapa ammentaa elämänkulkutoimijuudesta siinä, että toimijuus nähdään ajallisesti muuttuvana, yksilökehityksellisenä jatkumona, jonka perusta on menneisyydessä ja orientaatio tulevaisuudessa. Toimijuus ilmenee tekemisenä ja sitoutumisena, jota määrittävät kuhunkin elämänkulun kontekstiin ja aikaan liittyvät tekijät (Biesta \& Tedder 2007; de Vos ym. 2020).

Tarkastelemme korkeakoulutetun identiteettiä erityisesti urapolkukerronnan avulla. 'Identiteetti' on ajassa prosessimaisesti muuttuva käsitys itsestä, ja toimijuuden tavoin se muotoutuu sosiaalisessa todellisuudessa ja vuorovaikutuksessa (Butler 1990; Burr 2003; LaPointe 2011). Käytämme 'identiteettiä' rinnakkain 'uraidentiteetin' kanssa, ja molemmat käsitteet asemoituvat urakerronnan kontekstiin.

Uraidentiteetti kuvaa sitä, mitä yksilö on tai haluaa olla työssään (Meijers 1998). Se pohjautuu yksilön arvoihin, arvostuksiin ja merkityksen etsintään omalle elämälleen. Toisin sanoen uraidentiteetti kertoo, miten yksilöllä on tarve arvostaa itseään ja toimia omien arvojensa pohjalta työssään (Hall 1976; Martela \& Pessi 2018).

Elämänsuunta toteuttaa laajemminkin sitä, mitä ja miten yksilö haluaa olla suhteessa toisiin ihmisiin työnsä kautta (Meijers 1998; Martela \& Riekki 2018). Sosiaaliset toimintakehykset luovat raamit yksilön toimijuudelle ja identiteetille, jolloin yksilö asemoi itseään sekä suhteessa itseensä että näihin raameihin (Eteläpelto ym. 2014; Vanhalakka-Ruoho 2014).

\section{TUTKIMUSAINEISTO JA NARRATIIVINEN LÄHESTYMISTAPA ANALYYSISSA}

Tutkimus toteutettiin Euroopan sosiaalirahaston (ESR) vuosiksi 2015-2018 rahoittaman ”Töissä.fi- verkkopalvelu opiskelijan ja ohjaajan tukena” -hankkeen aikana. Helsingin ja Jyväskylän yliopistojen yhteishankkeessa kehitettiin verkkopohjaisia uraohjauspalveluja. Töissä.fi-palvelun käyttäjät kirjoittivat kuvauksia työstään ja urastaan verkkolomakkeelle. Siinä kysyttiin esimerkiksi vastaajan taustatietoja sekä sitä, mitä reittiä vastaaja oli päätynyt nykyiseen työhön ja mistä opinnoista oli ollut eniten hyötyä työssä. Vastaajat olivat korkeakoulutettuja, ja osallistuminen oli vapaaehtoista. Kirjoitelman tekemiseen kannustivat muun muassa hankkeen aikaiset kirjoittamiskampanjat ja uutiskirjeet korkeakouluista valmistuneille.

Keväällä 2017 Töissä.fi-palvelusta koottiin koulutusaloittain kaikki valmistuneiden kirjoitelmat, joita kertyi 462. Aineisto oli kooltaan 380 sivua, ja yksittäiset uratarinat olivat pituudeltaan puolikkaasta kahteen A4-sivuun. Valmistuneiden kirjoitelmia kutsutaan 'uratarinoiksi', koska kertojat kuvaavat niissä kerronallisesti urapolkujaan koulutuksesta työelämään. Uratarinoiden kirjoittajat olivat valmistuneet vuosina 1974-2017, ja heitä oli kaikista 14 suomalaisesta yliopistosta ja kaikista 23 suomalaisesta ammattikorkeakoulusta (Opetus- ja kulttuuriministeriö 2017). Osa näistä yliopistoista ja ammattikorkeakouluista on vaihtanut nimeään tai yhdistynyt viime vuosikymmeninä. Lisäksi korkeakouluissa on tapahtunut muutoksia muun muassa sen myötä, kun ammattikorkeakouluja ryhdyttiin perustamaan 1990-luvulla.

Kirjoittajat edustivat 140 koulutusalaa tai -ohjelmaa. Aineistossa oli 377 yliopistosta valmistuneen ja 85 ammattikorkeakoulusta valmistuneen kirjoitelmaa. Naiset kirjoittivat 250 kirjoitelmaa (54\%) ja miehet 103 kirjoitelmaa (22\%). Nimimerkillä kirjoitettiin 109 kirjoitelmaa (24\%), eikä näistä voinut päätellä sukupuolta.

Aineiston analyysissa käytetyllä narratiivisella lähestymistavalla on monia yhteisiä piirteitä toimijuuden ja identiteetin tarkastelun kanssa. Ensinnäkin narratiivisessa analyysissa kiinnitetään huomiota erityisesti kerronnan siirtymiin ja käännekohtiin, joissa myös yksilön toimijuutta haastetaan aktiivisesti esimerkiksi sisäisin tai ulkoisin estein (Elder ym. 2003; Hitlin \& Elder 2007). Toiseksi siinä korostuu ajatus 


\section{KERRONTAA VOIDAAN}

\section{PIT $\ddot{A} \ddot{A}$ MERKITYKSENANNON}

PROSESSINA.

yksilön identiteetin rakentumisesta kerronnallisten kokemusten kautta (Hyvärinen 2006), joita niin ikään etenkin subjektikeskeisessä ja elämänkulkututkimuksen lähestymistavoissa toimijuuteen korostetaan. Kolmanneksi konteksti on sekä toimijuuden että narratiivisen lähestymistavan kannalta keskeistä: kerronta sijoittuu aina tiettyyn aikaan, paikkaan ja sosiaaliseen struktuuriin (Tökkäri \& Perttula 2010; Eteläpelto ym. 2014).

Tämän tutkimuksen kontekstin muodostavat suomalainen korkeakoulutus ja sen jälkeinen työelämän urapolku yhteiskunnassa mahdollisuuksineen ja haasteineen. Korkeakoulutettujen uria on aiemmin tarkasteltu suomalaisessa tutkimuksessa narratiivisella lähestymistavalla tutkittaessa muun muassa yhteisöpedagogien pedagogista osaamista ja ammatillisen identiteetin rakentumista (Virkkala 2020), ammattikorkeakoulun opettajien urakertomuksia (Marttila 2015) sekä naisjohtajien urakehitystä (Ekonen 2007). Tutkimuksen aineisto kattaa laaja-alaisesti kaikki suomalaiset korkeakoulut ja lukuisat koulutusalat, mikä mahdollistaa korkeakoulutettujen urien monipuolisen narratiivisen tarkastelun.

Uraidentiteettiä muodostaessaan yksilö reflektoi työhön liittyviä kokemuksia merkityksineen jatkumoksi (Meijers 1998; Adamson ym. 1998; Meijers \& Wesselingh 1999; Anttila 2011). Oman identiteetin hahmottuminen vahvistaa yksilön itseluottamusta ja rohkaisee katselemaan erilaisia tulevaisuuden mahdollisuuksia (Murray 2004), jotka rakentavat hänen uraidentiteettiään (Meijers \& Wesselingh 1999; Anttila 2011). Narratiivinen lähestymistapa on aiemmin korostanut yksilön tarvetta yhtenäiseen kerrontaan, joka jäsentää hänen identiteettiään ja paikkaansa maailmassa (Hyvärinen 2006). Sittemmin yhtenäisen ja samalla lineaarisesti ja kronologisesti etenevän kerronnan ihannetta on alettu tarkastella kriittisesti, koska se muun muassa jättää varjoonsa monia kerronnallisia ilmiöitä ja traumakokemuksia, jotka eivät asetu koherenssin kehykseen (Hyvärinen ym. 2010, 1-15).

Kertomukset syntyvät tietyssä kontekstissa mutta ne myös muokkaavat ja luovat uusia konteksteja ja käytäntöjä (de Fina \& Georgakopoulou 2015, 3). Narratiivisen tutkimuksen metodologinen keskustelu onkin jakautunut kahtia muun muassa siinä, painotetaanko sosiaalista vai yksilöllistä näkökulmaa. Tähän keskusteluun liittyy toimijuuden ja identiteetin käsitteiden tarkastelu narratiivisessa tutkimuksessa. Tällöin etenkin yksilön kokemuksia tarkastelevassa tutkimuksessa toimijuutta ja identiteettiä pidetään keskeisinä, kun taas tapahtumiin keskittyvässä tutkimuksessa toimijuuden tarkastelu jää vähemmälle huomiolle. (Squire ym. 2013, 7.)

Kerronta voidaan nähdä merkityksenannon prosessina. Tällöin kokemuksille annetaan merkityksiä ja siten rakennetaan omaa identiteettiä, joka muotoutuu sosiaalisessa vuorovaikutuksessa. Sosiaalipsykologi Vilma Hännisen (1999) mukaan identiteetit rakentuvat kulttuurisista aineksista. Hänen kehittämässään tarinallisen kiertokulun teoriassa ihmiset liittävät aineksia sisäiseen tarinaansa sosiaalisesta tarinavarannosta. Siihen kuuluvat kulttuuriset mallitarinat välittyvät esimerkiksi sosiaalisessa vuorovaikutuksessa ja median kautta. Sisäinen tarina on prosessimainen, ja ihmisellä voi olla lukuisia keskenään hierarkkisia, rinnakkaisia tai jopa ristiriitaisia sisäisiä tarinoita. (Hänninen 1999.) Kirjallisuudentutkija Shlomith Rimmon-Kenanin (2002) mukaan henkilökohtaiset kertomukset muodostuvat yleensä kulttuurisia, suuria kertomuksia noudattaviksi tai vastakkaisiksi näille. Mallitarinat voivat olla rajoittavia määritellessään, miten on oikein toimia kulttuurin sääntöjen ja odotusten mukaisesti. Samalla niiden avulla voi saada vapauttavia ideoita valita toisin ja rakentaa kerrontaansa uudella tavalla. (Hänninen 1999; LaPointe 2011.)

Aineiston analyysin ensimmäisessä vaiheessa hyödynsimme Amia Lieblichin, Rivka Tuval-Mashiachin ja Tamar Zilberin (1998, 62-63) narratiivisen holistisen sisällön analyysin mallia. Siinä valitaan kunkin kertomuksen tähtäyspiste ja keskeiset teemat, joita seurataan kertomuksen alusta loppuun. Uratarinoita tarkasteltiin myös narratiivisen holistisen muodon 
RIKAS JA LAAJA

KERRONNALLINEN AINEISTO

MAHDOLLISTI TYYPPI-

TARINOIDEN MUODOSTAMISEN.

analyysin avulla, joka auttoi tunnistamaan uratarinan juonen dynamiikkaa esimerkiksi etenevän tai polveilevan tyylin suhteen (Lieblich ym. 1998, 89-91).

Analyysin toisessa vaiheessa hyödynsimme Donald Polkinghornen (1995) mallia siitä, miten kerronnallisesta aineistosta luodaan narratiivisen analyysin tuloksena uusi kertomus. Kertomuksen rakentamisessa on keskeistä määritellä loppuratkaisu, joka tutkimuksessamme oli tutkittavan urapolun rakentumisen ja omien uraratkaisujen tekemisen tapa. Ensimmäisen ja toisen analyysivaiheen pohjalta hahmottui seitsemän uratyyppiä, jotka nimettiin urapolun rakentumista kuvaavalla tavalla: 1) suunnitelmalliset, 2) osaamisen tunnistajat, 3) aktiiviset, 4) sattuman kuljettamat, 5) intohimon ohjaamat, 6) polveilijat ja 7) yrittäjähenkiset. Kunkin kirjoittajan uratarina sijoitettiin yhden uratyypin alle sen mukaan, mitä uratyyppiä se parhaiten vastasi.

Analyysin ensimmäisen ja toisen vaiheen tulokset esitetään uratyyppitarinoina vastauksena ensimmäiseen tutkimuskysymykseen, millaisia urapolkuja korkeakoulutettujen uratarinoista on tunnistettavissa. Lukija saa näin mahdollisimman monipuolisen kuvauksen eri uratyypeistä, sillä uratyyppitarinat koottiin usean samaan ryhmään kuuluneen uratarinan pohjalta. Rikas ja laaja kerronnallinen aineisto mahdollisti tyyppitarinoiden muodostamisen (ks. myös Virkkala 2020; Ekonen 2007). Tyyppitarinoiden avulla aineistoa voidaan juonentaa synteesiksi (Polkinghorne 1995) ja pelkistää tiettyjen teemojen näkökulmasta (Hänninen 1999).

Eettisestä näkökulmasta tyyppitarinat suojaavat tutkimukseen osallistuneiden tunnistamattomuutta (Hänninen 2010). Ne tosin irrottavat uratarinat tarkemmasta kontekstistaan, mutta analyysivaiheessa määrittelimme kertomuksen loppuratkaisuksi urapolun rakentumisen tavan, joka ei näyttänyt olevan vahvasti sidoksissa esimerkiksi sukupuoleen, koulutusalaan tai korkeakouluasteeseen.

Analyysin kolmannessa vaiheessa tarkastelimme aiemmin muodostettuja uratyyppitarinoita vielä teoriaohjaavan analyysin avulla. Rakensimme tutkimuksen keskeisistä käsitteistä, toimijuudesta ja identiteetistä, aiemman tutkimuksen avulla teoreettiset määritelmät, analyysi-ikkunat. Niiden avulla tarkastelimme toisen tutkimuskysymyksen mukaisesti, millaisia toimijuuden ja identiteetin yksilöllisiä ja sosiaalisia painotuksia korkeakoulutettujen uratyyppitarinat sisälsivät. Teoriaohjaavan analyysin pohjaksi 'toimijuus' määriteltiin ajallisesti muuttuvaksi prosessiksi, joka ilmenee yksilön vaikuttaessa, tehdessä valintoja ja päätöksiä sekä ottaessa kantaa työhönsä ja ammatillisiin identiteetteihinsä sosiaalisessa todellisuudessa (Eteläpelto ym. 2014). 'Identiteetti' puolestaan määriteltiin siksi, mitä yksilö on tai haluaa olla työssään suhteessa itseensä ja toisiin ihmisiin (Hall 1976; Meijers 1998).

Koska korkeakoulutettujen toimijuus ja identiteetti painottuivat uratyyppitarinoissa eri tavoin yksilöllisesti tai sosiaalisesti ja määrittivät tarinoita vahvasti, esitämme ennen uratyyppitarinoiden kuvausta kootusti eri uratyyppien yleisyyden aineistossa sekä asemoitumisen yksilöllisesti ja sosiaalisesti painottuneen toimijuuden ja identiteetin näkökulmasta (taulukko 1). Toimijuuden ja identiteetin painottuminen yksilöllisesti tai sosiaalisesti kuvasti sitä, miten yksilöllisesti ja itsenäisesti tai sosiaalisesti ja ympäröivän yhteiskunnan vaikutuksia heijastellen eri uratyypit tekivät yhtäl̈lä toimijoina omaa uraansa koskevia valintoja ja toisaalta määrittivät omaa identiteettiään.

Uratyypit (taulukko 1) asemoituivat eri tavoin yksilöllisesti tai sosiaalisesti painottunutta identiteettiä tai toimijuutta kuvastaen. Suunnitelmalliset ja polveilijat edustivat sekä yksilöllisesti että sosiaalisesti painottuneen identiteetin piirteitä. Osaamisen tunnistajat kuvasivat puolestaan sekä yksilöllisesti että sosiaalisesti painottuneen toimijuuden piirteitä. Aktiiviset, sattuman kuljettamat, intohimon ohjaamat ja yrittäjähenkiset asemoituivat selkeämmin joko yksilöllisen tai sosiaalisen toimijuuden ja identiteetin painotuksen mukaan. Uratyypit kuvataan järjestyksessä yleisimmästä harvinaisempaan. 
Taulukko 1. Korkeakoulutettujen uratyyppien yleisyys aineistossa sekä uratyyppien asemoituminen yksilöllisesti ja sosiaalisesti painottuneen toimijuuden ja identiteetin näkökulmasta.

\begin{tabular}{|c|c|c|c|c|c|}
\hline Uratyypit & $\begin{array}{r}\text { Yleisyys } \\
\text { aineistossa } \\
\text { (uratarinoiden } \\
\text { määrä ja } \\
\text { \%-osuus) }\end{array}$ & $\begin{array}{r}\text { Yksilöllisesti } \\
\text { painottunut } \\
\text { toimijuus }\end{array}$ & $\begin{array}{r}\text { Sosiaalisesti } \\
\text { painottunut } \\
\text { toimijuus }\end{array}$ & $\begin{array}{l}\text { Yksilöllisesti } \\
\text { painottunut } \\
\text { identiteetti }\end{array}$ & $\begin{array}{l}\text { Sosiaalisesti } \\
\text { painottunut } \\
\text { identiteetti }\end{array}$ \\
\hline Suunnitelmalliset & $148(32 \%)$ & $x$ & & $x$ & $x$ \\
\hline Osaamisen tunnistajat & $82(18 \%)$ & $x$ & $x$ & & $x$ \\
\hline Aktiiviset & $81(18 \%)$ & $x$ & & & $x$ \\
\hline Sattuman kuljettamat & $53(11 \%)$ & & $\mathrm{x}$ & & $x$ \\
\hline Intohimon ohjaamat & $47(10 \%)$ & $x$ & & $x$ & \\
\hline Polveilijat & $28(6 \%)$ & & $x$ & $x$ & $x$ \\
\hline Yrittäjähenkiset & $23(5 \%)$ & & $x$ & $x$ & \\
\hline
\end{tabular}

SUUNNITELMALLISET: "OLISI HYVÄ, JOS PYSTYISI HETI VALMISTUTTUAAN VALITSEMAAN OMAN URAN"

Suunnitelmalliset olivat kulkeneet koulutus- ja työelämässä suoraviivaista ja tavoitteellista urapolkua pitkin, mikä kuvasti heidän yksilöllisesti painottunutta toimijuuttaan ja identiteettiään. He kokivat, että uraa koskevat ratkaisut olivat heidän omissa käsissään, ja heillä oli selkeä halu tehdä juuri kyseistä työtä. Samalla suunnitelmalliset aistivat pohdinnoissaan vahvasti ympäröivää yhteiskuntaa ja sen realismia esimerkiksi työllistymismahdollisuuksissa, mikä määritti heidän identiteettinsä sosiaalisesti painottunutta puolta:

"Opiskelin yliopistossa pääaineenani kirjallisuutta. Kun poikaystäväni eli nykyinen mieheni rupesi vapaaksi taiteilijaksi, tarvitsin ammatin, jossa voi ansaita elannon. Ensin soitin kaikki kustantajat läpi ja kysyin, pääseekö niihin töihin. Kun ilmeni, että vaihtuvuus koko maassa on yksi työntekijä per vuosi, aloin opiskella sivuaineena suomen kieltä. Taisin jo silloin tähdätä äidinkielen opettajaksi. Kun aineopintoja oli tarpeeksi, menin opetusharjoitteluun. Valmistuin 1980-luvun lopulla äidinkielen ja kirjallisuuden opettajaksi, työllistyin yliopiston harjoittelukouluun, ja tämän kuukauden lopussa jään eläkkeelle.”
Suunnitelmallisille olivat tärkeitä niin sitoutuminen opiskeluun ja työhön kuin koulutus- ja työelämän jatkumot:

"Opiskeluun kannattaa sitoutua. Vain siten valmistuu ja pääsee taas eteenpäin. Olisi hyvä, jos pystyisi heti valmistuttuaan valitsemaan oman uran ja syventämään osaamistaan siinä."

Suunnitelmalliset korostivat jatkuvaa reflektointia niin koulutus- kuin työuran eri vaiheissa. Kaiken kaikkiaan he edustivat eniten perinteistä yhden työuran tyyppiä.

\section{OSAAMISEN TUNNISTAJAT: "TÄRKEÄMPÄÄ KUIN SE, MITÄ ON OPISKELLUT, ON TIETÄÄ, MITÄ OSAA"}

Osaamisen tunnistajat painottivat kerronnassaan kykyä sanoittaa ja markkinoida omaa osaamista sekä edetä siten työuralla, mikä kuvasti heidän osin yksilöllisesti painottunutta toimijuuttaan:

"Opintoni eivät ole tuoneet minulle tiettyä ammattia, mutta yleissivistävä kokonaisuus on antanut paljon tarvittavia työelämätaitoja. Itsestään kannattaa brändätä osaaja jo opiskeluvaiheessa ja ajatella työn hakeminen markkinointiprojektina, jossa omaa osaamista kaupataan." 


\section{SATTUMAN KULJETTAMAT}

\author{
KUVASIVAT PALJON \\ VERKOSTOJEN MERKITYST $\ddot{A}$.
}

Osaamisen tunnistajille oli lisäksi tärkeää aistia yhteiskunnallista tilannetta ja sen osaamistrendejä, miltä osin heidän toimijuutensa painottui sosiaalisesti. He korostivat omien vahvuuksiensa reflektointia toisten tuella ja määrittivät näin sosiaalisesti painottuneessa identiteetissään oman osaamisensa riippuvuutta toisista ja työelämän vaatimuksista:

"Kuulin nykyisestä työpaikastani työhönvalmentajani kautta, joka myös tunsi työnantajani. Työhönvalmentajan asiakkaaksi meneminen oli selkeästi käännekohta työnhaussa. Sain valmentajan kautta tsemppiä osaamiseni markkinointiin ja reflektiota omaan työtilanteeseen. Lopulta tärkeämpää kuin se, mitä on opiskellut, on tietää, mitä osaa.”

Oman osaamisen tunnistaminen oli siis heille tärkeintä omien uraratkaisujen tekemisessä. Osaamisen tunnistajille ominaista oli ennen kaikkea sitkeys ja omien kykyjen myyminen eteenpäin.

\section{AKTIIVISET: "SINNIKKYYS JA AKTIIVINEN OTE PALKITAAN AINA, ENNEMMIN TAI MYÖHEMMIN"}

Aktiiviset etenivät aktiivisesti omalla urallaan, mikä kuvasi heidän yksilöllisesti painottunutta toimijuuttaan: he etsivät ja hyödynsivät oma-aloitteisesti koulutus- ja työelämän tarjoamia mahdollisuuksia. Aktiiviset olivat työskennelleet jo opiskeluaikana, ja monet olivat olleet opiskelijavaihdossa:

”Alun perin tulin nykyiseen työpaikkaani suorit-
tamaan toisen vuoden harjoittelujakson ja kesä-
töihin. Kolmantena vuonna tulin taas kesätöihin
mutta avautui tilaisuus jäädä töihin talven yli. Sii-
hen aikaan opinnot joustivat, ja sain työn ja kou-
lun yhdistettyä. Tein myös opinnäytetyön tähän
työpaikkaan töiden ohessa. Kansainvälinen aktii-
visuus opintojen aikana auttaa, ja yleensäkin ak-
tiivisuus opiskeluaikana erilaisissa järjestöissä ja ryhmissä auttaa etenkin työuran alussa. Tärkeintä on olla itse aktiivinen ja tehdä ihan jokainen työtehtävä niin hyvin kuin osaa."

Aktiivisten tarinoissa esiintyivät usein termit aktiivisuus, sinnikkyys ja rohkeus. Heidän sosiaalisesti painottuneessa identiteetissään korostuivat verkostot ja suhteet, joilla oli ollut heille suuri merkitys niin koulutus- ja työelämän kuin uramahdollisuuksien löytämisessä:

"Sinnikkyys ja aktiivinen ote palkitaan aina, ennemmin tai myöhemmin. Rohkeutta on se, että tekee vaikka pelkää. Lisäksi verkostoista on apua hyvinkin nopeasti."

Aktiiviset korostivat sitä, että kaikkiin mahdollisuuksiin kannattaa tarttua ja katsoa, minkälaisia uusia polkuja avautuu. He olivat myös todenneet, että nykyään moniin työtehtäviin löytyy toinenkin polku, jollei heti aluksi ole hoksannut hakeutua oikealle reitille.

\section{SATTUMAN KULJETTAMAT: "EHKÄ LOPULTA KYSE ON VAIN OLLUT SUUNNITELLUSTA SATTUMASTA"}

Sattuman kuljettamien kerronnassa esiintyi usein sattuma-termi, esimerkiksi "sattuma puuttuu peliin". Sattuma ilmeni heidän urapolullaan usein siten, että joku toinen henkilö, kuten tuttava tai esimies, tunnisti heidän osaamisensa, ja he päätyivät johonkin koulutukseen tai työpaikkaan. Tämä kuvasti heidän sosiaalisesti painottunutta toimijuuttaan, jossa heidän uravalintojaan ohjasivat vahvimmin ulkopuoliset tekijät:

"Olen päätynyt nykyiseen työhöni aika pitkän mutkan kautta. Työskentelin monta vuotta Venäjällä ja Suomessa. Lopulta pienen haeskelun ja muutaman työtehtävän kokeilun jälkeen hain nykyiseen tehtävääni. Tähän työhön olen päätynyt, vaikka reitti tähän pisteeseen on kulkenut ennen muuta sattumien ja hetken mielijohteiden kautta. Ehkä lopulta kyse on vain ollut suunnitellusta sattumasta, eli siitä, että ihminen tiedostamattaan hakeutuu kiinnostustaan vastaavalle uralle."

Sattuman kuljettamat kuvasivat paljon verkostojen merkitystä, mikä kertoi heidän sosiaalisesti painottuneesta identiteetistään, jossa suhteet toisiin olivat etusijalla oman uraidentiteetin määrittelyssä: 
"Monesti paras tie unelmien työpaikkaan vie monen mutkan kautta. Verkostoja kannattaa luoda heti alusta alkaen sekä työpaikalla että mahdollisten yhteistyökumppaneiden kanssa ja huolehtia, että ihmiset muistavat jatkossakin 'hyvänä tyyppinä.”

Sattuman kuljettamien kerronnassa nimensä mukaisesti usein sattuma oli vaikuttanut heidän elämäänsä juuri verkostojen ja suhteiden välityksellä.

\section{INTOHIMON OHJAAMAT: "INTOHIMOSTANI ON TULLUT OMA TYÖ"}

Intohimon ohjaamat etenivät urallaan jonkin johtoajatuksen ohjaamina. Intohimosta käsin toimiminen kuvasi heidän yksilöllisesti painottunutta toimijuuttaan:

"Tutkimusryhmässä tehdyn gradun myötä innostuin tutkimuksesta, ja jatkoin tohtorin tutkintoon samassa tiimissä. Väitöskirja ja filosofian tohtorin tutkinto valmistuivat pienen perheenlisäysviivytyksen jälkeen, ja seuraavana vuonna sain määräaikaisen paikan yliassistenttina. Muutaman vuoden kuluttua lehtorimme eläköityi, ja koska tehtävä painottui opetukseen ja koulutuksen kehittämiseen, se kiinnosti minua kovasti. Kokemukseni opetussuunnitelmatyöstä oli antanut minulle tehtävää ajatellen tarvittavia valmiuksia, ja sinä syksynä aloitinkin nykyisessä työssäni yliopistonlehtorina."

Arvojen ja oman intohimon tiedostaminen kertoi intohimon ohjaamien yksilöllisesti painottuneesta identiteetistä, joka oli rakentunut omien arvojen ja kiinnostuksen kohteiden syvällisen reflektoinnin avulla:

"Olen päässyt pitkälle, koska olen ollut omille kyvyilleni, toiveilleni ja persoonalleni rehellinen ja luottanut vaistooni. Intohimostani on tullut oma työ."

Intohimon ohjaamat korostivat, että on tärkeää hahmotella itselleen, millainen unelmien työpaikka on. He kokivat, että silloin usein ajautuu samalla unelmaansa kohti.

\section{POLVEILIJAT: "VAIN HARVAT TEKEVÄT KOKO TYÖURANSA YHDEN ALAN JA YHDEN TYÖNANTAJAN ALAISUUDESSA"}

Polveilijat olivat kulkeneet koulutus- ja työuransa polveilevaa polkua pitkin. Heidän urapolkunsa varrella oli muun muassa työpaikan vaihtoja, irtisanomisia ja työttömyyttä. Polveilijoiden sosiaalisesti painottuneessa toimijuudessa etenkin koulutus- ja työelämän todellisuudella, kuten työmarkkinatilanteella, oli vahva eikä aina toivottu vaikutus heidän uravalintoihinsa:

”Käytännössä aloitin työnhaun kunnolla vasta, kun työt tutkijana olivat loppuneet ja oli aikaa keskittyä hakemiseen. Kirjoitin ja hioin hakemuksia ajan kanssa, ja pääsin kevään aikana kuuteen yritykseen työhaastatteluun, kun lähetettyjä hakemuksia oli reilu 20. En lannistunut ensimmäisestä tai edes kymmenennestä ei:stä, vaan jatkoin työnhakua. Vajaan neljän kuukauden työnhaun jälkeen aloitin nykyisessä työpaikassani tutkimus- ja tuotekehitystyöt nimikkeenäni software engineer. Asiat siis järjestyivät hyvin, vaikka jättäydyin niin sanotusti tyhjän päälle, kun lopetin tutkijan hommat."

Polveilijoiden kulkua urapolulla kuvasivat selviytymisen ja sitkeyden termit. Suhteet toisiin sekä koulutus- ja työelämän todellisuuteen olivat määrittäneet heidän omaa paikkaansa, mikä oli vaikuttanut heidän osin sosiaalisesti painottuneeseen identiteettiinsä. Samalla polveilijat olivat pohtineet paljon omia arvojaan ja hyvinvointiaan polveilevan urapolkunsa vuoksi, mikä märitti heidän osin yksilöllisesti painottunutta identiteettiään:

"Kannattaa siis olla utelias, ottaa riskejä ja hypätä tuntemattomaan. On hyvä muistaa, että heti ei tarvitse tietää, mikä sinusta tulee koulutuksen jälkeen - askelmerkit kyllä selkiytyvät koulutuksen aikana. Vain harvat tekevät koko työuransa yhden alan ja yhden työnantajan alaisuudessa. Lyhyet työsuhteet kuten sijaisuudet ja projektit eivät ole ongelma, jos itse huolehtii itsestään.” 


\section{KOLMANNES AINEISTOSTA}

\section{OLI SUUNNITELMALLISTEN}

\section{URATARINOITA.}

Polveilijat korostivat omaa hyvinvointiaan siksikin, että monet heistä olivat olleet pätkätöissä, jolloin kenelläkään muulla ei ollut kokonaiskuvaa heidän edellisistä lomistaan.

\section{YRITTÄJÄHENKISET: "YRITTÄJYYS ON SEIKKAILU, JOSSA ON HYVIÄ JA HUONOJA PÄIVIÄ"}

Yrittäjähenkisiin kuuluivat eri korkeakoulualoilta yrittäjiksi ryhtyneet. Heidän valintaansa selittivät muun muassa oman alan rakennemuutokset. He elivät yritystoiminnassa vahvasti tiimin ja työtilauksien armoilla. Nämä asiat kuvastivat yrittäjähenkisten sosiaalisesti painottunutta toimijuutta, jossa yhteiskunnan suhdanteet ja verkostot ohjasivat merkittävästi toimijuuden raameja ja intensiteettiä:

"Olin pitkään yksityisessä yrityksessä töissä, kunnes päätin perustaa oman yrityksen aiemman työnantajan fuusioiduttua ja tehtävänkuvani muututtua. Töitä tehdään silloin, kun niitä on usein myös öisin ja viikonloppuisin. Työni on hyvin itsenäistä, mutta lopullinen tulos on aina kiinni koko tiimin onnistumisesta. Taloudellisesti on välillä haastavia aikoja.”

Yrittäjähenkisillä oli monipuolista osaamista, ja heidän kerronnassaan kuvastui mahdollisuus elää omaa osaamista todeksi yrittäjänä. Vahva reflektointi omasta suunnasta, kehittymisestä ja kyvystä toteuttaa itseä määrittivät yrittäjähenkisten yksilöllisesti painottunutta identiteettiä:

"Yrittäjyys vaatii kykyä uudistua ja rohkeutta luottaa, että huomenna on paremmin, kun tänään teemme yrityksessä oikeita asioita. Yrittäjänä pääsee toteuttamaan itseään aivan eri lailla kuin 'oikeissa töissä'. Yrittäjyys on seikkailu, jossa on hyviä ja huonoja päiviä."
Vaikka yrittäjähenkiset kertoivatkin, että heidän palkkansa on pienempi kuin työntekijänä, vapaus toteuttaa itseään oli heille tärkeämpi arvo kuin raha.

\section{POHDINTA}

Tarkastellessamme toimijuuden ja identiteetin yksilöllisiä ja sosiaalisia painotuksia korkeakoulutettujen uratarinoissa loimme aineiston analyysin pohjalta seitsemän uratyyppitarinaa. Ne nimettiin urapolun rakentumista kuvaavalla tavalla. Uratyyppitarinat vastasivat ensimmäiseen tutkimuskysymykseen, millaisia urapolkuja korkeakoulutettujen uratarinoista oli tunnistettavissa. Uratyypit olivat 1) suunnitelmalliset, 2) osaamisen tunnistajat, 3) aktiiviset, 4) sattuman kuljettamat, 5) intohimon ohjaamat, 6) polveilijat ja 7) yrittäjähenkiset. Uratyyppitarinoiden teoriaohjaavan analyysin avulla tarkastelimme toisen tutkimuskysymyksen mukaisesti, millaisia toimijuuden ja identiteetin yksilöllisiä ja sosiaalisia painotuksia korkeakoulutettujen uratarinat sisälsivät.

Korkeakoulutettujen toimijuus ja identiteetti painottuivat uratarinoissa eri tavoin yksilöllisesti tai sosiaalisesti, mitä kuvattiin uratyyppitarinoissa. Yksilöllinen painotus korostaa selkeitä ja tietoisia itsestä lähteviä uratavoitteita, jotka suuntaavat yksilöiden valintoja ja päätöksiä itsenäisesti rakennetuilla urapoluilla. Vastaavasti sosiaalinen painotus korostaa muiden ihmisten ja sosiaalisen kontekstin merkitystä niin oman urapolun hahmottamisessa kuin sen rakentumisessa. Esimerkiksi suunnitelmallisilla suoraviivainen ja tavoitteellinen urapolku kuvasti yksilöllisesti painottunutta toimijuutta ja identiteettiä. Sattuman kuljettamien uravalintoja ohjasivat puolestaan merkittävästi ulkopuoliset tekijät kuten tuttavien ja esimiesten suositukset sekä verkostot, mikä kuvasti niin heidän sosiaalisesti painottunutta toimijuuttaan kuin identiteettiään.

Tuloksemme vahvistavat aiempaa näkemystä toimijuuden ja identiteetin yhteenkietoutumisesta. Ensinnäkin identiteetti voidaan ymmärtää toimijuutta suuntaavana (esim. Eteläpelto ym. 2013; Eteläpelto ym. 2014). Toiseksi tulokset luovat uutta ymmärrystä toimijuuden ja identiteetin vuorovaikutuksellisuudesta uratutkimuksen viitekehyksessä 


\section{ERI URATYYPIT OLIVAT}

TUNNISTETTAVISSA

\section{URATARINOISTA ERI}

KOULUTUSALOILLA JA SEK $\ddot{A}$

NAISTEN ETT $\ddot{A}$ MIESTEN

URAKERRONNASSA.

(esim. LaPointe 2014; de Vos ym. 2020; Rantanen ym. 2021). Samalla ne valottavat toimijuuden ja identiteetin painotusten yksilöllisyyttä ja vaihtelevuutta sekä yhteyttä sosiaaliseen todellisuuteen, sillä eri ihmisillä toimijuus ja identiteetti muodostavat erilaisia yksilöllisesti ja sosiaalisesti painottuneita kombinaatioita uraan ja urasuunnitteluun liittyen.

Tuloksissa havaitsemiemme uratyyppien toimijuuden ja identiteetin yksilölliset ja sosiaaliset painotukset seuraavat uudempien urateorioiden (esim. Lent ym. 1996; Savickas 2005; Niles 2011) ja urakäsitysten (esim. Hall 1976; Arthur \& Rousseau 2000) korostamia piirteitä, kuten yksilöllisten elämäntarinoiden rakentumista sekä yksilön ja sosiaalisen ympäristön välistä vuorovaikutusta (esim. de Vos ym. 2020).

Tarkastelemalla uratyyppitarinoiden toimijuutta ja identiteettiä voidaan pohtia, miten vastata käytännössä uusien urateorioiden soveltamisen haasteisiin (Onnismaa 2003; de Vos ym. 2020). Ensinnäkin uratyyppitarinat tekevät näkyviksi ura- ja elämänsuunnittelun kysymysten monimutkaisuuden, jolloin eri tavoin yksilöllisesti ja sosiaalisesti painottuneen toimijuuden ja identiteetin asemoituminen tuottaa tarkentavaa tietoa uraa koskevan päätöksenteon ja uraohjauksen tarpeisiin. Toiseksi toimijuuden ja identiteetin yksilöllinen ja sosiaalinen painotus ovat niissä yhtäaikaisesti läsnä, mikä luo pohjaa ura- ja elämänsuunnittelun moniulotteiselle tarkastelulle. Kolmanneksi narratiivinen lähestymistapa uratarinoihin tarjoaa mahdollisuuden tarkastella kokonaisvaltaisesti yksilön elämänkenttää ja -kulkua. Uratarinoiden pohjalta rakennetut uratyyppitarinat kuvaavat korkeakoulutettujen tyypillisiä urapolkurakenteita mutta tuovat samalla esiin polku- jen rikkauden, jossa toimijuutta ja identiteettiä nähdään eri muodoissaan niin aktiivisuutena kuin vetäytymisenä (vrt. Vanhalakka-Ruoho 2014) ja niin suunnitelmallisena, polveilevana kuin sattuman kuljettamana (vrt. Mitchell ym. 1999).

Aineistossa oli eniten (32\%) suunnitelmallisten ryhmään kuuluneiden uratarinoita. Heidän tarinansa voidaan nähdä kulttuurista, perinteistä mallikertomusta noudattavana kerrontana (Hänninen 1999; Rimmon-Kenan 2002), miten henkilöt opiskelevat tiettyyn ammattiin ja tekevät työtä yhdellä työuralla eläkeikään asti (esim. Super 1954; Holland 1985). Suunnitelmallisten ryhmän suuruutta voi selittää myös rajoittavana tekijänä aineiston aikajänne, sillä uratarinansa kirjoittaneet olivat valmistuneet vuosina 1974-2017, ja monet edustivat osin jo ammattikorkeakoulujen perustamista edeltävää ajanjaksoa. Ikäjakauma vaikuttaa osaltaan kerronnan tapaan, jossa jo aiemmin korkeakouluista valmistuneet opastavat nuorempia korkeakoulutettuja.

Tutkimuksemme erittäin merkittävä tulos on kuitenkin se, että kuusi muuta uratyyppiä, jotka voidaan nähdä osin vastakkaisina suunnitelmallisten tarinalle, muodostivat yhdessä enemmistön, noin kaksi kolmannesta (68\%) aineiston uratarinoista. Kun otetaan huomioon aineiston laajuus ( $\mathrm{N}=462)$ ja kattavuus, tulos tuo esiin muuttuvan yhteiskunnan osin mahdollistaman ja osin säätelemän urapolkujen suuren kirjon. Tämä haastaa niin koulutus- ja työllisyyspolitiikan kuin koulutuksen ja ohjauksen toimijat pohtimaan, miten tunnistaa ja tukea korkeakoulutettujen urapolkujen rakentumisen moninaisia tapoja (ks. myös Rantanen 2018) ja erilaisia kulttuurisia mallitarinoita, kuten korkeakoulutettujen osaamisen tunnistamista ja yrittäjähenkisyyttä (esim. Laalo \& Jauhiainen 2019), korostavaa kerrontaa.

Tutkimustuloksissa oli merkittävää sekin, että aineistosta tunnistetut korkeakoulutettujen uratyypit eivät olleet vahvasti sidoksissa koulutusalaan tai sukupuoleen, vaan eri uratyypit olivat tunnistettavissa uratarinoista eri koulutusaloilla ja sekä naisten että miesten urakerronnassa. Tulosten valossa on tärkeää huomioida toimijuuden ja identiteetin yksilöllinen ja sosiaalinen tarkastelu sekä korkeakoulutettujen urapolkuja ja työllistyvyyttä tutkittaessa että käytännön koulutus- ja työllisyyspoliittisia linjauksia pohdittaessa. (vrt. Vuorinen-Lampila 2014.) 
Yksilöt tarvitsevat tukea urasuunnitteluunsa sekä eri elämänvaiheissa että nopeasti muuttuvien urien ristipaineessa (Lampi ym. 2019; OECD 2021), jotta eri tyyppiset toimijuuden ja identiteetin rakentumisen polut voivat rakentua onnistuneesti. Esimerkiksi alaa vaihtava aikuinen tarvitsee tukea henkilökohtaiselle identiteettityölleen, mikä edellyttää ohjaustyötä tekeviltä asiantuntijoilta herkkyyttä tunnistaa näitä prosesseja sekä ihmisten yksilöllisiä tarpeita ja arvoja (Heikkilä 2019; Lampi ym. 2019).

Ohjattavan toimijuutta tavoitteleva ja osallisuuden kokemuksen kautta identiteetin huomioiva ohjaus voi tukea niin yksilöä kuin yhteisöä (LaPointe 2014; Vehviläinen 2014). Vahva ja selkeä toimijuus ja identiteetti tukevat merkittävästi paitsi yksilön hyvinvointia (ks. myös Rantanen 2018; Järvensivu \& Pulkki 2019) myös organisaatioiden menestystä ja uusiutumiskykyä työelämän murroksissa (de Vos \& van der Heijden 2017). Urapolkujen moninaisuuden tunnistavalla ja hyväksyvällä uraohjauksella vahvistetaan koko yhteiskuntaa ja sen tulevaisuutta.

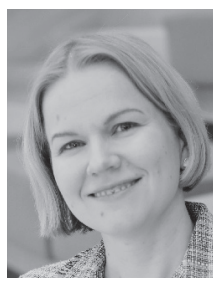

EIJA HANHIMÄKI

TT, KM, yliopistonopettaja kasvatustieteiden laitos Jyväskylän yliopisto

(iD https://orcid.org/0000-00020982-7288

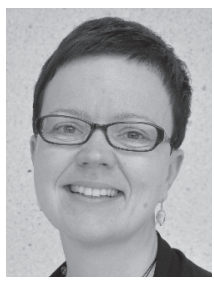

\section{KATJA VÄHÄSANTANEN}

$K T$, työelämän tutkimuksen ja kehittämisen dosentti, yliopistotutkija kasvatustieteiden laitos Jyväskylän yliopisto

(iD https://orcid.org/0000-00033521-4802

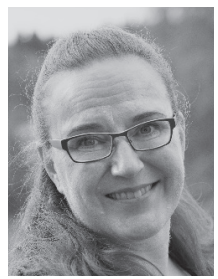

\section{JOHANNA RANTANEN}

PsT, työ- ja persoonallisuuspsykologian dosentti, yliopistonlehtori psykologian laitos Jyväskylän yliopisto

(iD) https://orcid.org/0000-00034945-8533

LÄHTEET.

Adamson, S. J., Doherty, N. \& Viney, C. (1998). The Meanings of Career Revisited: Implications for Theory and Practice. British Journal of Management, 9(4), 251-259. https://doi.org/10.1111/1467-8551.00096

Akava Works (2021). Työttömyyskatsaus 5/2021: Pitkäaikaistyöttömiä on jo yli sata tuhatta. https:// akavaworks.fi/julkaisut/tyottomyyskatsaukset/05-21pitkaaikaistyottomia-jo-yli-sata-tuhatta (29.6.2021).

Anttila, K. (2011). Opiskelijan uraidentiteetistä ja sen kehittämisestä. Teoksessa J. Kaisto \& J. O. Liimatainen (toim.) Asiantuntijaksi kasvun tukeminen korkeakoulussa. Ajatuksia urasta, asiantuntijuudesta ja opiskelun etenemisestä. Ohjaus- ja työelämäpalvelut. Oulun yliopisto. Oulu: Kalevaprint, 5-12.

Arnold, J. \& Jackson, C. (1997). The New Career: Issues and Challenges. British Journal of Guidance and Counselling, 25(4), 427-433. https://doi. org/10.1080/03069889708253821

Arthur M. B. \& Rousseau, D. M. (2000). The boundaryless career as a new employment principle. Teoksessa M. B. Arthur \& D. M. Rousseau (toim.) The Boundaryless Career. New York: Oxford University Press, 295-306.
Biesta, G. \& Tedder, M. (2007). Agency and learning in the lifecourse: Towards an ecological perspective. Studies in the Education of Adults, 39(2), 132-149. https://doi.org/10.1080/02660830.2007.11661545

Burr, V. (2003). Social constructionism. 2. painos. London, New York: Routledge.

Butler, J. (1990). Gender trouble: Feminism, and the subversion of identity. New York, NY: Routledge.

Carruthers, B. \& Uzzi, B. (2000). Economic sociology in the new millennium. Contemporary Sociology, 29(3), 486-494. https://doi.org/10.2307/2653936

Ekonen, M. (2007). Moninaiset urat - Narratiivinen tutkimus naisjohtajien urakehityksestä. Lisensiaatintutkimus. Jyväskylä: Jyväskylän yliopisto.

Elder, G. H. Jr., Johnson, M.K. \& Crosnoe R. (2003). The emergence and development of life course theory. Teoksessa J. Mortimer \& M. Shanahan (toim.) Handbook of the Life Course. New York: Plenum, 3-22.

Eteläpelto, A., Vähäsantanen, K., Hökkä, P. \& Paloniemi, S. (2013). What is agency? Conceptualizing professional agency at work. Educational Research Review 10, 45-65. https://doi.org/10.1016/j. edurev.2013.05.001 
Eteläpelto, A., Vähäsantanen, K., Hökkä, P., \& Paloniemi, S. (2014). Miten käsitteellistää ammatillista toimijuutta työssä?. Aikuiskasvatus, 34(3), 202-214. https://doi.org/10.33336/aik.94100

Fina, de, A. \& Georgakopoulou (2015). Introduction. Teoksessa A. De Fina \& A. Georgakopoulou (toim.) Handbook of Narrative Analysis. Malden, MA: John Wiley \& Sons Inc., 1-15.

Findikaattori (2021). Väestön koulutusrakenne. https:// findikaattori.fi/fi/9 (29.6.2021).

Goller, M. \& Paloniemi, S. (toim.) (2017). Agency at Work: an agentic perspective on professional learning and development. Cham: Springer.

Hall, D. (1976). Careers in Organizations. California: Goodyear Publishing Company.

Heikkilä, M. (2019). Alanvaihto ja ammatillisen identiteetin muutos ruumiillisina tiloina ja tuntemuksina. Aikuiskasvatus, 39(1), 19-33. https:// doi.org/10.33336/aik.80228

Hitlin, S. \& Elder, G. H. (2007). Time, self and the curiously abstract concept of agency. Sociological Theory, 25(2), 170-191. https://doi.org/10.1111/ j.1467-9558.2007.00303.x

Holland, J. L. (1985). Making Vocational Choices. A Theory of Vocational Personalities \& Work Environments. 2. painos. New Jersey: Prentice-Hall.

Hyvärinen, M. (2006). Kerronnallinen tutkimus. http:// www.hyvarinen.info/page02-kerrot.html

Hyvärinen, M., Hydén, L. C., Saarenheimo, M., \& Tamboukou, M. (2010). Beyond narrative coherence: An introduction. Teoksessa M. Hyvärinen, L.-C. Hydén, M. Saarenheimo \& M. Tamboukou (toim.) Beyond Narrative Coherence. Amsterdam/Philadelphia: John Benjamins Publishing Company, 1-15.

Hänninen, V. (1999). Sisäinen tarina, elämä ja muutos. Acta Universitatis Tamperensis 696. Diss. Tampere: TAJU.

Hänninen, V. (2010). Narratiivisen tutkimuksen käytäntöjä. Teoksessa I. Aaltola \& R. Valli (toim.) Ikkunoita tutkimusmetodeihin II. 3. täydennetty painos. Jyväskylä: PS-Kustannus, 160-178.

Isopahkala-Bouret, U. \& Siivonen, P. (2016). Viisikymppisten naisten neuvottelua korkeakoulutuksesta, ikääntymisestä ja työllistettävyydestä. Aikuiskasvatus, 36 (4), 246-257. https://doi.org/10.33336/aik.88510

Järvensivu, A. \& Pulkki, J. (2019). Työura: yksilön valintoja vai monimutkaista kehkeytymistä? Janus, 27(1), 38-54. https://doi.org/10.30668/janus.64170

Laalo, H., \& Jauhiainen, A. (2019). Yrittäjyyttä akatemiaan! Suomalaisen yliopistokoulutuksen problematisoituminen yrittäjyysdiskurssissa. Aikuiskasvatus, 39(2), 92-107. https://doi. org/10.33336/aik.82983
Lampi, E., Vähäsantanen, K., \& Rantanen, J. (2019). Uraohjaajien osaaminen ja haasteet työelämän murroksessa. Aikuiskasvatus, 39(3), 208-220. https:// doi.org/10.33336/aik.85710

LaPointe, K. (2011). Moral struggles, subtle shifts: narrative practices of identity works in career transitions. Diss. Helsinki: Aalto University

LaPointe, K. (2014). Tilaa mielekkäälle työlle. Aikuiskasvatus, 34(1), 17-28. https://doi. org/10.33336/aik.94071

Lent, R. W., Brown, S. D. \& Hackett, G. (1996). Career development from a social cognitive perspective. Teoksessa D. Brown, L. Brooks \& Associates (toim.) Career choice and development. 3. painos. San Francisco: Jossey-Bass, 373-421.

Lieblich, A., Tuval-Mashiach, R. \& Zilber, T. (1998). Narrative Research. Reading, Analysis, and Interpretation. Applied Social Research Methods Series Volume 47. Tousand Oaks, CA: Sage.

Martela, F. \& Pessi, A. B. (2018). Significant Work Is About Self-Realization and Broader Purpose: Defining the Key Dimensions of Meaningful Work. Frontiers in psychology 9. https://doi.org/10.3389/fpsyg.2018.00363

Martela, F., \& Riekki, T. J. J. (2018). Autonomy, competence, relatedness, and beneficence: A multicultural comparison of the four pathways to meaningful work. Frontiers in Psychology 9. https:// doi.org/10.3389/fpsyg.2018.01157

Marttila, L. (2015). Ura kerronnallisena työnä ammattikorkeakoulun opettajat kertojina. Väitöskirja. Tampere: Tampere University Press. https://trepo.tuni.fi/ handle/10024/97123

Mauno, S., Minkkinen, J. \& Auvinen, E. (2019). Nakertaako työn intensiivisyyden lisääntyminen työssä suoriutumista ja työn merkityksellisyyttä?: Vertaileva tutkimus eri ammattialoilla. Hallinnon Tutkimus, 38(4), 271-288. https://doi.org/10.37450/ht.98052

Meijers, F. (1998). The development of career identity. International Journal for the Advancement of Counselling, 20(3), 191-207. https://doi. org/10.1023/A:1005399417256

Meijers, F. \& Wesselingh, A. (1999). Career identity, education, and new ways of learning. International Journal of Contemporary Sociology, 36(2), 299-251.

Mitchell, K. E., Levin, A. S. \& Krumboltz, J. D. (1999). Planned happenstance: constructing unexpected career opportunities. Journal of counseling and development, 77(2), 115-124. https://doi. org/10.1002/j.1556-6676.1999.tb02431.x

Murray, M. (2004). Narrative psychology. Teoksessa J. Smith (toim.) Qualitative psychology: a practical guide to research methods. London: Sage, 111-131.

Niles, S. (2011). Career Flow: A hope-centered model of career development. Journal of Employment Counseling, 48(4), 173-175. https://doi. org/10.1002/j.2161-1920.2011.tb01107.x 
OECD (2021). Career Guidance for Adults in a Changing World of Work. Getting Skills Right. Paris: OECD Publishing. https://doi.org/10.1787/9a94bfad-en

Ojala, K., Isopahkala-Bouret, U., \& Haltia, N. (2018). Osaaminen ja kilpailukyky YAMK-tutkinnon suorittaneiden suhteellisen työmarkkina-aseman määrittäjinä. Aikuiskasvatus, 38(4), 291-303. https:// doi.org/10.33336/aik.88374

Onnismaa, J. (2003). Epävarmuuden paluu. Ohjauksen ja ohjausasiantuntijuuden muutos. Kasvatustieteellisiä julkaisuja n:o 91. Väitöskirja. Kasvatustieteiden tiedekunta, Joensuun yliopisto. http://urn.fi/ URN:ISBN:952-458-304-6

Onnismaa, J. (2011). Ohjaus- ja neuvontatyö. Aikaa, huomiota ja kunnioitusta. Helsinki: Gaudeamus.

Opetus- ja kulttuuriministeriö (2017). Korkeakoulut, tiedelaitokset ja muut julkiset tutkimusorganisaatiot. http:// minedu.fi/korkeakoulut-ja-tiedelaitokset (30.11.2017).

Polkinghorne, D. (1995). Narrative configuration in qualitative analysis. Teoksessa J. Amos Hatch \& R. Wisniewski (toim.) Life History and Narrative. London: Falmer Press, 5-24.

Rantanen, J. (2018). Onko hoppu? -kehittämistutkimus: Yliopisto-opiskelijoiden urasuunnittelutaitojen ja työelämävalmiuksien vahvistaminen. Student Life -hankkeen loppuraportti, Jyväskylän yliopisto. http:// urn.fi/URN:ISBN:978-951-39-7581-4

Rantanen, J., Lyyra, P., Feldt, T., Villi, M. \& Parviainen, T. (2021). Intensified Job Demands and Cognitive Stress Symptoms: The Moderator Role of Individual Characteristics. Frontiers in Psychology 12. https://doi. org/10.3389/fpsyg.2021.607172

Rimmon-Kenan, S. (2002). The Story of "I": illness and narrative identity. Narrative, 10(1), 9-27.

Rouhelo, A. (2008). Akateemiset urapolut. Humanistisen, yhteiskuntatieteellisen ja kasvatustieteellisen alan generalistien urapolkujen alkuvaiheet 1980-ja 1990-luvuilla. Väitöskirja. Turku: Turun yliopisto.

Rouhelo, A. (2009). Akateemisten generalistien urapolut. Työelämän tutkimus, 7(3), 221-225.

Sampson, J. P., Hou, P. C., Kronholz, J., Dozier, C., McClain, M. C., Buzzetta, M., Pawley, E., Finklea, T., Peterson, G. P., Lenz, J. G., Reardon, R. C., Osborn, D. S., Hayden, S. C. W., Colvin, G. P., \& Kennelly, E. L. (2014). Annual review: A content analysis of career development theory, research, and practice - 2013. The Career Development Quarterly 62 (4), 290-326. https://doi.org/10.1002/j.2161-0045.2014.00085.x

Savickas, M. L. (2005). The theory and practice of career construction. Teoksessa S.D. Brown \& R.W. Lent (toim.) Career development and counseling. Hoboken, NJ: Wiley, 42-70.

Squire, C., Andrews, M. \& Tamboukou, M. (2013). Introduction: What is Narrative Research? Teoksessa M. Andrews, C. Squire \& M. Tamboukou (toim.) Doing Narrative Research. SAGE Publications, 1-27.
Super, D. E. (1954). Career patterns as a basis for vocational counseling. Journal of Counseling Psychology, 1, 12-20. https://doi.org/10.1037/h0061989

Terrén, E. (2002). Post-Modern Attitudes: a challenge to democratic education. European Journal of Education, 37(2), 161-177. https://doi.org/10.1111/1467-3435.00100

Tomlinson, M. (2008). "The degree is not enough": Students' perceptions of the role of higher education credentials for graduate work and employability. British Journal of Sociology of Education, 29(1), 49-61. https:// doi.org/10.1080/01425690701737457

Työ- ja elinkeinoministeriö (2016). Korkeasti koulutettujen työmarkkinapolut. Työllisyys, työttömyys ja syrjäytymisriski. Työ- ja elinkeinoministeriön julkaisuja. Työ ja yrittäjyys. 22/2016. http://julkaisut.valtioneuvosto. fi/bitstream/handle/10024/75049/TEMjul_22_2016_netti. pdf? sequence=1\&isAllowed=y (20.4.2020).

Tökkäri, V., \& Perttula, J. (2010). Itsensä kehittäminen johtajien kertomuksissa. Aikuiskasvatus, 30(2), 120 129. https://doi.org/10.33336/aik.93869

Vanhalakka-Ruoho, M. (2014). Toimijuus elämänkulussa ohjaustyön perusta?. Aikuiskasvatus, 34(3), 192-201. https://doi.org/10.33336/aik.94099

Vehviläinen, S. (2014). Ohjaustyön opas. Yhteistyössä kohti toimijuutta. Helsinki: Gaudeamus.

Virkkala, S. (2020). Yhteisöpedagogiksi tulemisen tarinat. Narratiivinen tutkimus pedagogisen osaamisen ja ammatillisen identiteetin rakentumisesta yhteisöpedagogiopintojen aikana. Väitöskirja. Jyväskylä: Jyväskylän yliopisto. http://urn.fi/ URN:ISBN:978-951-39-8286-7

Vos, de, A. \& van der Heijden (2017). Current thinking on contemporary careers: The key roles of sustainable HRM and sustainability of careers. Current Opinion in Environmental Sustainability 28, 41-50. https://doi. org/10.1016/j.cosust.2017.07.003

Vos, de, A., van der Heijden, B. I. \& Akkermans, J. (2020). Sustainable careers: Towards a conceptual model. Journal of Vocational Behavior, 117. https://doi. org/10.1016/j.jvb.2018.06.011

Vuorinen-Lampila, P. (2014). Korkeakoulutettujen työelämänäkymät. Talous ja Yhteiskunta, 3, 42-47.

Vähäsantanen, K., Paloniemi, S., Räikkönen, E., Hökkä, P. \& Eteläpelto, A. (2017). Ammatillisen toimijuuden moniulotteinen rakenne ja mittarikehittely. $K$. Vähäsantanen, S. Paloniemi, P. Hökkä \& A. Eteläpelto (toim.) Ammatillinen toimijuus. Rakenne, mittari ja tuki. Jyväskylä: Jyväskylän yliopisto. 14-33. http://urn.fi/ URN:ISBN:978-951-39-6980-6

Åkerblad, L. (2014). Epävarmuuden tuolla puolen. Muuttuvat työmarkkinat ja prekaari toimijuus. Väitöskirja. Joensuu: Itä-Suomen yliopisto. http://urn.fi/ URN:ISBN:978-952-61-1364-7 